\title{
An ICT supported sociocultural approach to improve the teaching of physics
}

\author{
Nhung Nguyen ${ }^{1,3^{*}}$ and P. John Williams ${ }^{2}$
}

\author{
* Correspondence: \\ hnn3@students.waikato.ac.nz \\ ${ }^{1}$ Can Tho University, Can Tho, \\ Vietnam \\ ${ }^{3}$ TEMS Education Research Centre, \\ the University of Waikato, Private \\ Bag 3105, Hamilton 3240, New \\ Zealand \\ Full list of author information is \\ available at the end of the article
}

\begin{abstract}
In many countries there is evidence of the international educational movement toward more student centred and technology supported teaching as a way to better prepare students for the future. This has been the focus in Vietnam, for example, since the education reform agenda developed in 2000, but the little evidence that there is seems to indicate that teaching remains largely didactic and teacher centred. This research is a response to the Vietnamese context, and consists of the theorization, development and implementation of a model which integrates student centred pedagogies with information and communication technologies. The data collected related to the implementation of the model, from both the teacher and the students, suggests that this may be a helpful way for teachers to move toward a more student centred pedagogy which is supported by available technologies.
\end{abstract}

Keywords: Physics, Student-centred, Sociocultural, Constructivist, Information communication technology, Vietnam, Theory, Model, Pedagogy, Theoretical model

\section{Introduction}

Integrating information communication technology (ICT) into education is a focus of many countries around the world (Peeraer and Van Petegem 2011). The results of previous studies indicate that ICT can be used to effectively support students' learning (Driver 1988; Kamali-Mohammadzadeh et al. 2014; Ojugo et al. 2013; Ozkal et al. 2009; Rovai 2004). In Asia-Pacific, many Ministries of Education are promoting ICT in education and the use of ICT to support a student-centred approach (Peeraer and Van Petegem 2011; UNESCO 2005). In line with this trend in the Asian-Pacific region, Vietnam's government is driving a reform in education, and an important goal is to promote innovative teaching and learning methods (National Assembly of Vietnam 2000). The goal is to change education from a teacher-centred to a student-centred approach (Prime Minister of Vietnam 2005), and ICT is promoted to be integrated in Vietnam's education system (Vietnam's Ministry of Education and Training 2008) as one way to achieve this goal. However, after about one and a half decades of innovation, the teaching and learning approach in Vietnam is still rather teachercentred (Pham 2010; Stephen et al. 2006).

It is argued by Harman and Nguyen (2010) that Vietnamese teachers are now facing the challenges of technology-driven education; the critical need for teachers in this context is to acquire new understandings and skills in using ICT to support teaching in the light of a student-centred approach. However, there is very little national

(c) 2016 The Author(s). Open Access This article is distributed under the terms of the Creative Commons Attribution 4.0 International License (http://creativecommons.org/licenses/by/4.0/), which permits unrestricted use, distribution, and reproduction in any medium, provided you give appropriate credit to the original author(s) and the source, provide a link to the Creative Commons license, and indicate if changes were made. 
literature which could inform Vietnamese teachers on how to use ICT underpinned by a student-centred approach in their teaching context.

The goal of the research reported here is based on these goals and needs. The research goal is to trial and to evaluate a pedagogic model which integrates appropriate learning principles with ICT in teaching Physics in the context of Vietnam. The research question, therefore, is: How does the application of the model influence students' physics learning?

\section{Theoretical framework}

ICT is defined by UNESCO as forms of technology used for creating, displaying, storing, manipulating, and exchanging information (Meleisea 2007). This broad definition includes all forms of information communication technology. ICT today is commonly thought of as relating to electronic and digital forms of technology such as computers, networks, e-mail, internet, telephone, television, radio and so forth. The focus of ICT in this study is the use of Internet, software, multimedia resources, and course management systems.

Figure 1 presents the Pedagogic Theoretical Model of Integrating Constructivist and Sociocultural Learning Principles with ICT (CSI Model). In general, the nature of learning can be explained by sociocultural and cognitive constructivist points of view: learning occurs in social context (sociocultural theories) and involves the creation and selforganisation of knowledge (cognitive constructivism) by the individual.

\section{Learning principles}

The first learning principle is based on the sociocultural view that learning occurs in social contexts. Learning from a sociocultural perspective is discussed by Salomon and Perkins (1998), who distinguish meanings of social learning. Some of these meanings are:

- active social mediation of individual learning,

- social mediation as participatory knowledge construction,

- social mediation by cultural scaffolding.

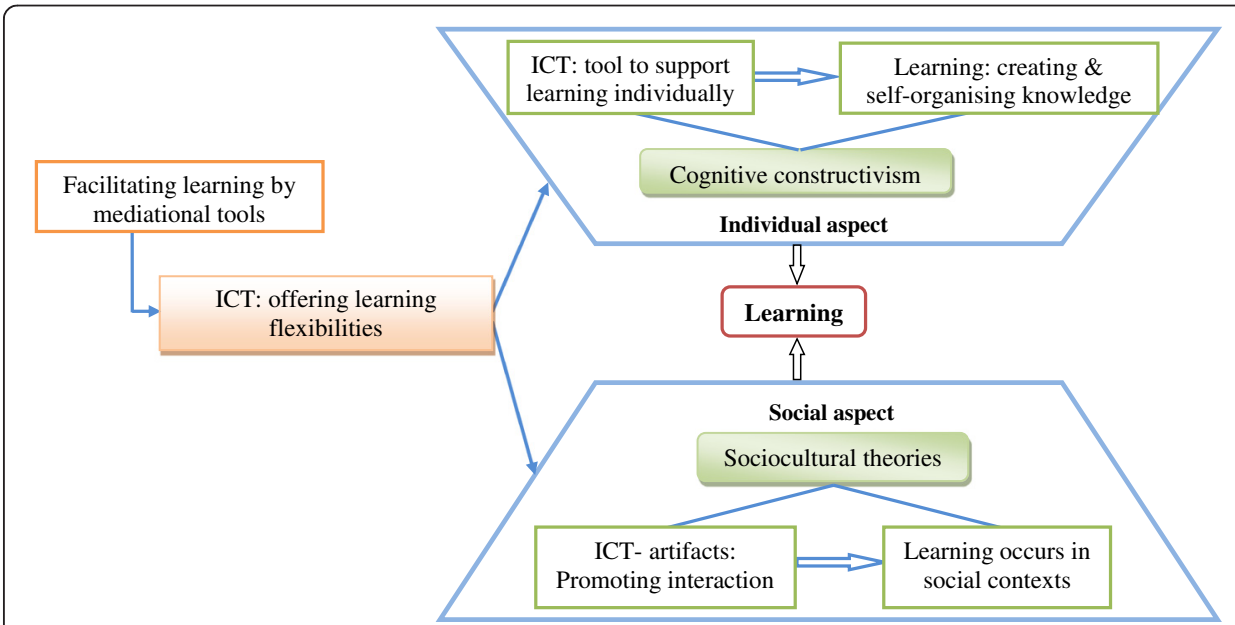

Fig. 1 The Pedagogic Theoretical Model of Integrating Constructivist and Sociocultural Learning Principles with ICT (The CSI Model) 
This model (Fig. 1) concentrates on the above meanings of the learning for the following reasons. The first meaning of learning - Active social mediation of individual learning - reflects the idea that in society, facilitating agents (i.e., a team or a person) help an individual to learn by providing the learner with guidance, tasks, feedback and scaffolding. Facilitating agents, in this case, may be teachers, tutors or peers.

The second meaning of learning - Social mediation as participatory knowledge construction - views learning as participating in a social process of knowledge construction. This type of outlook is also shared by several researchers in the field including Cole (1995), Salomon and Perkins (1998), and Greeno (1997).

Social mediation of learning and the individual involved are seen as integrated and highly situated system in which the interaction serves as the socially shared vehicles of thought. Accordingly, the learning products of this system, jointly constructed as they are, are distributed over the entire social system rather than possessed by the participating individual. (Salomon and Perkins 1998, p. 4)

Cognition (i.e., intelligence or knowledge) is distributed across social systems among people, learners, cultures, artifacts, environments and situations (Pea 1997; Salomon and Perkins 1996; Salomon and Perkins 1998). It is argued that cognition is accomplished rather than possessed by individuals participating in learning activities (Pea 1997; Salomon and Perkins 1998), and "learning is participation in social practice" (Greeno 1997, p. 9). In other words, according to these authors, cognition or intelligence is achieved by participating in social activities.

According to Pea (1997), the distribution of cognition has two dimensions: social and material. The social distribution of cognition relates to the cognition constructed by participating in social organised activities such as working in groups to accomplish shared goals. In this outlook, acquisition of learners' knowledge and skills occurs when they participate in social practices (Cobb and Bowers 1999; Greeno 1997; Salomon and Perkins 1998). Therefore, "discussion of alternative arrangements for learning needs to include consideration of the values of having students learn to participate in the practices of learning that those arrangments afford"(Greeno 1997, p. 10). The material distribution of cognition concerns the cognition constructed by utilising artifacts to accomplish activities' goals.

Inclining to the view that learning is facilitated by participating in social practices (Cobb and Bowers 1999; Lave and Wenger 1991), it is argued that "knowledge is situated, being in part a product of activity, context, and culture in which it is developed and used" (Brown et al. 1989, p. 32). Besides the notion that learning is situated in contexts and activities, cultural views also emphasise interactive activity systems in which learners interact with other people (i.e., other learners, teachers and tutors) as well as artifacts (i.e., tools, ICT and learning resources) (Cobb and Bowers 1999; Cole and Wertsch 1996; Greeno 1997).

Social mediation by cultural scaffolding - the third meaning of learning - is interpreted by Salomon and Perkins (1998) as learning which is mediated by cultural artifacts such as tools (e.g., books, photos and videos) and information sources. 
Such artifacts can range from books and videotapes that tacitly embody shared cultural understandings to statistical tools and socially shared symbols embodying, for instance, a "language of thinking" that includes such finely distinguished terms as hypothesis, conjecture, theory, and guess. (Salomon and Perkins 1998, p. 5)

ICT, from this perspective, can be considered as cultural artifacts that are able to facilitate learning.

From the constructivist perspective, learners create and self-organise their own knowledge in order to learn (Fig. 1) (Fosnot and Perry 2005; Von Glasersfeld 1989). This learning principle concerns the human internal process of constructing knowledge (cognitive constructivism). Learning normally starts by observing or experiencing, continues with making meaning and relating current experiences to cognitive systems which learners have previously developed. Learners then integrate or differentiate the new knowledge; thus, the new balance in their cognitive system is formed. Based on this theory of learning, teachers can facilitate student learning by offering them as many opportunities as possible to observe and to experience in a learning context (Watts and Pope 1989). The teaching content should consider learners' prior knowledge (Driver and Oldham 1986; Ozkal, et al. 2009). Teachers need to provide appropriate help so that learners can relate new information to prior cognitive systems, then make the change and enrich their understanding.

\section{ICT facilitating learning in social contexts}

ICT can facilitate learning (Fig. 1) by providing learning flexibilities (Collis and Moonen 2001). This section will explain how ICT as an artifact may promote interaction and facilitate the co-construction of knowledge in social contexts. It is considered that interaction in this model contains interaction between $\mathrm{k}$ students - teachers, (2) students - students and (3) students - learning materials and tasks.

According to Collis and Moonen (2001), learning flexibilities relate to learning resources such as textbooks, books and online resources. Beside traditional resources (i.e., textbooks, books and other resources in libraries), students are provided with opportunities to access unlimited online resources created by scientists, experts, lecturers, peers and communities. These resources are rich as well as variable in format, for example texts, photos, diagrams, animations, audios and videos. Students have opportunities to interact with the learning resources, exploit these ICT artifacts to engage in meaningful learning activities and co-construct knowledge (Pea 1997; Salomon and Perkins 1998).

The flexibilities provided by ICT extend to methods of communication such as faceto-face, telephone, e-mail, chat, video conferencing and forum (Collis and Moonen 2001). The communication can be synchronous or asynchronous. These flexibilities in communication offer opportunities for teachers and students to promote discussion and interaction (Amanatidis 2014; García-Valcárcel et al. 2014; Jonassen et al. 1995). As discussed earlier, discussion and interactions among learners and learners-teachers in interactive social systems are the corner stones of learning which is based on a sociocultural approach. The power of ICT as sociocultural artifacts is reflected in capabilities to promote discussion and interaction. With the support of the communication function of ICT, students can work in groups, solve problems or conduct designed learning 
tasks. They can present their arguments, negotiate meaning and co-construct their knowledge. Besides interacting with their peers, ICT is able to provide students with opportunities of interaction with teachers, tutors and experts from whom they can get support, guidance and scaffolding (Butter et al. 2014). By providing a wide range of choices in communication methods, ICT can support and enhance the students' learning.

Collis and Moonen (2001) also point out that ICT can offer students choices in instructional organisation including forms of course-organisation (e.g., face-to-face and online), time, place and pace of study. Furthermore, ICT also supports alternatives in the social organisation of learning (e.g., working in groups, working individually and combination). The flexible choices offered by ICT provide learners with a variety of opportunities to participate in learning activities and social practices without depending too much on physical places. The participation in social practices by students crosses physical locations and occurs online when individual students can be in different places (e.g., at home, in café, in library and so on) and work together on a shared task. Students can also participate in learning activities any time. To a certain extent, they can also decide their pace of study, language, and method of working in groups and/or individually. The above flexibilities which are facilitated by ICT encourage learners to participate in social systems and engage with new knowledge.

Students' knowledge is constructed when they achieve shared goals. The students learn by participating in interactive social systems in which individuals interact with each other (students and teachers) and interact with artifacts (i.e., ICT), including learning resources designed by teachers and others (Greeno 1997; Salomon and Perkins 1996). The flexibilities of ICT in terms of communication, instructional organisation, time, place, social organisation of learning can help to promote interaction and discussion within the interactive social systems, therebypotentially enhancing students' learning.

\section{ICT facilitating individual learning}

ICT, from the cognitive constructivist point of view, is a tool for learners to construct knowledge individually (Fig. 1). As discussed above, learning from the cognitive constructivist perspective is a process of learner-organised knowledge. ICT offers rich learning material and resources that can help learners to observe, experience and make sense of new phenomena in a supportive environment.

Jonassen et al. (1998) point out how ICT tools such as search engines, hypermedia and visualisation tools can assist learners to construct their knowledge. The authors argue that with the huge volume and the accelerating escalation of information, it is necessary for learners to have a tool that supports them to access and process information. Search engines such as Google, Bing and Yahoo can help learners to access and locate the information sources (i.e., websites) which are appropriate for their needs. The websites in general present information in many forms including texts and visual ads (e.g., photos, diagrams, audios and videos). Jonassen et al. (1998) note that the learners internalise more information through their visual modality than other sensory modalities. Therefore, the visual additions such as colours, photos, audios and videos could be considered useful tools to assist learners to construct their own knowledge. 
Furthermore, the information in the websites can be organised in linear or hypermedia structures. A link in hypermedia may connect to a full website or a photo, a diagram, texts, an audio or a video file. The link enables information to be organised in structured form which show meaningful relationships between/among groups of information. With the links, learners are able to navigate the information resources, learn the organisation of the information sources and organise/re-organise their own knowledge. Many hypermedia websites allow learners to add and modify the content and the links of the websites. By modifying and creating hypermedia websites and content, learners reflect their understanding of the knowledge and the organisation of the knowledge.

ICT in the light of a constructivist learning principle can also provide students with opportunities to construct their knowledge in symbolic forms (e.g., words, diagrams and photos), and organise the knowledge in a structured system (e.g., mind map, structured folder and database) (Salomon 1998). Jonassen et al. (1998) state that ICT visualisation tools assist learners to reason visually and convey their mental images. For instance, software that is used to draw mind maps (e.g., MINDMAP, SmartDraw and FreeMind) can be an effective tool for students to organise ideas and refine the organisation of the ideas. Drawing software and animation design software are examples of ICT tools support learners representing their mental images.

\section{Research methods}

\section{Research goal and research questions}

The goals of the research are to trial and evaluate the CSI model which integrates social cultural and constructivist learning principles with ICT in teaching Physics in the context of Vietnam.

The research question: How does the application of the CSI Model influence students' physics learning?

The main research question is specified into research sub questions:

1. How does the application of the CSI Model influence on students' physics content knowledge?

2. What are teachers' opinions on the application of the CSI Model?

3. What are students' attitudes and opinions on the application of the CSI Model?

\section{Research framework}

A lecturer implemented the CSI Model in teaching two groups of students: Group 1 and Group 2. The extents of the CSI Model implementation were different between the two groups. Group 2 experienced the application of the model without the support of an online learning management system while Group 1 fully experienced the CSI model implementation (with the use of an online learning management system called LMS (Learning Management System)). It was noted that before participating in this project, the lecturer had not used any learning management system to support teaching and learning.

Before participating in this research, the lecturer's teaching strategy for his optics course could be described as: 
1. Prior to the classes:

- Students were asked to read optics learning materials.

2. In the classes:

- The lecturer gave optics lectures.

- The lecturer sometimes used MS PowerPoint to present or asked students to present optics topics.

- The lecturer asked students questions.

3. After classes:

- Students solved assignments.

When participating in this research and implementing the CSI model, his teaching strategy changed:

1. Prior to the classes: Students were asked to study optics topics by themselves

- Working in groups,

- Using a range of learning resources (e.g., textbooks, books and online resources).

- Designing presentations to explain the optics topics to their classmates in the coming classes.

- Sharing presentations on LMS (Group 1)

2. In the classes:

- Groups of students explained/presented optics topics to their classmates.

- Students and lecturers asked questions to presenters.

- Students asked lecturers questions.

3. After classes:

- Students solved assignments.

- Students prepared for next class.

- Students' online discussion- Forum on LMS (Group1).

The research used a quasi-experimental approach (Cohen et al. 2011; Muijs 2004; Walliman 2006) to examine the influence of the model on students' physics learning. This is presented in Fig. 2. The symbols in Fig. 2 were derived from Campbell and Stanley (1963) where:

- $\mathrm{O}_{1}$ : Pre-tests which are the same for both groups.

- $\mathrm{O}_{2}$ : Post-tests which are the same for both groups.

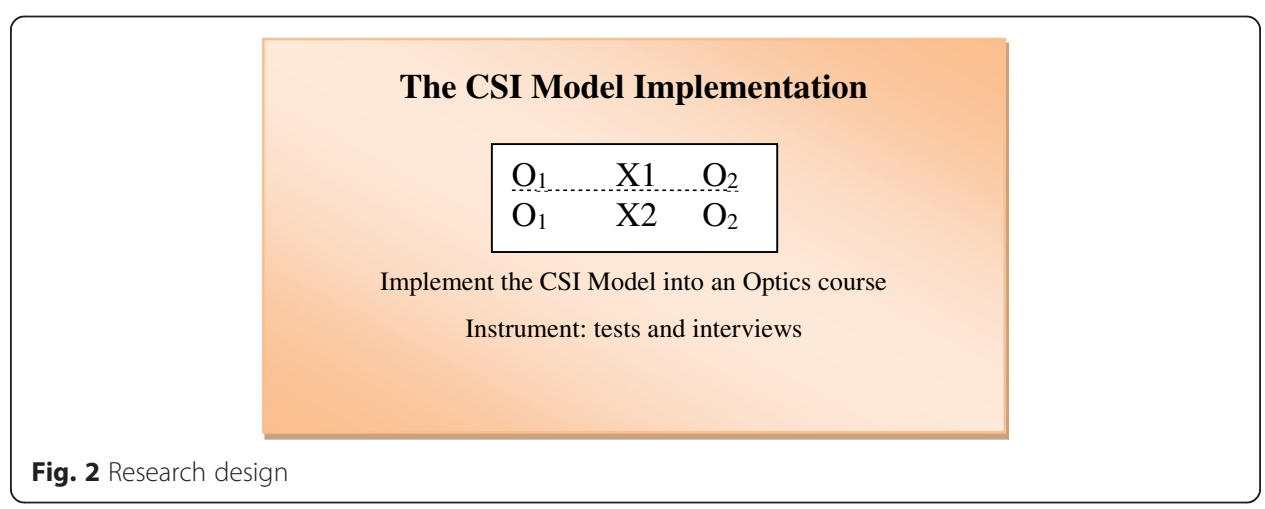


- $\mathrm{X}_{1}$ : Exposure of Group 1 to the application of the CSI Model and an online learning management system.

- $X_{2}$ : Exposure of Group 2 to the application of the CSI Model (without an online learning management system).

The CSI Model was implemented by the lecturer in an optics course of a physics department within a school of education of a university in Vietnam. The lecturer participating in this research had applied some ICT in his teaching, and had required students to use ICT to make PowerPoint presentations related to optics topics in the past. Because the objective of the research is to investigate impacts of the CSI Model on physics learning, it was appropriate to invite a lecturer who had utilised ICT in education so that the lecturer can fully concentrate on implementing the model rather than becoming familiar with applying ICT in teaching practice.

The course was delivered over 16 weeks, one semester, including one week for orientation and one week for the examination. Ninety three students in four-year-degree programmes of a physics department at a school of education of a university in the south of Vietnam participated in this research. The students were training to be teachers at upper-secondary schools. Most of them were in the second year (87.6\%), though some were either in their first year $(7.8 \%)$ or in their third year $(5.6 \%)$. Of the students, $70 \%$ were female. In Vietnam, students normally finish upper-secondary school at the age of 18 and enter universities at 19. The average age of those involved in the research was 20.2 years with $64 \%$ being 20 years old.

The students self selected to be enrolled in a group (Group 1 and Group 2) based on their study timetables. The pre-test indicated that there was no significant difference between these two groups. The CSI Model was implemented in both groups with one difference in the application: Group 1 used an online learning management system for optics study while Group 2 did not.

\section{Data collection methods and quality assurance}

Both quantitative and qualitative methods were employed in this research to help triangulate, complement data, and so to ensure the quality of the research. In addition, data was collected from different groups of people (i.e., students, the lecturer and a teaching assistant). This allowed different perspectives from different groups of people to be examined.

The data collection methods included optics pre and post-tests and interviews. Interviews comprised two individual interviews with the lecturer, a teaching assistant and five focus group interviews with groups of students.

The test included 40 items and was designed by the lecturer, and the same test was used for pre- and post-tests. To examine if the students' optics performance had improved after the implementation of the CSI Model, the students' scores between pre-test and post-test were compared. As mentioned earlier, the implementation of the CSI Model into Group 1 and Group 2 was slightly different: Group 1 used LMS while Group 2 did not. Therefore, a comparison of students' scores between Group 1 and Group 2 will be conducted in order to investigate whether the 
use of LMS made a difference. t-test and Cohen's d were used to analyse data for the tests. SPPSS was employed to analyse the test results while NVivo was used to analyse interview data.

Un-structured interviews were conducted with the lecturer - Mr Van, and the teaching assistant. There were two lecturer interviews: an interview was conducted at week four of the semester, another was conducted at the end of the semester. The teaching assistant was interviewed just once. The interviews focused on their reflection on the influence of the CSI Model on learning and teaching.

Un-structured interviews, in Vietnamese, were carried out with groups of students in week seven (one interview), week fourteen (two interviews) and week fifteen (two interviews). Student focus group interviews were employed in this case in order to encourage students to engage in a rich discussion about the topic/question in groups. In this way, diversified perspectives on a topic/question might be presented and discussed deeply among students during the interviews. One of the disadvantages of focus group interviews was that it was hard to control. While some students dominated the discussions, others did not talk much. Interviewers needed to encourage the students who did not have chance to present their ideas by directing questions to them. The students voluntarily participated in the interviews, and each student participated in only one interview. The number of students in each group was from four to ten. The goal of the students' interviews was to record students' reflections on the implementation on the model:

- What the students think about the way that the Optics Course was taught.

- Whether this teaching model is suitable for them.

- The role of ICT in their learning process.

- The strong points and weaknesses of the course.

The interviews were coded, and the codes were categorised into nodes and themes (Cohen, et al. 2011).

\section{Results}

Influence of the CSI model application on students' physics content knowledge

Students' physics content knowledge in this research was evaluated by optics pre and post tests. This section will present findings from the test results.

\section{Students' post-test scores are statistically significantly higher than pre-test scores}

The paired-samples t-test was used to examine the impact of the model implementation. The results of the students' optics tests show that there are statistically significant differences between pre-test and post-test results of the students in both groups. In general, the test scores in the post-test are higher than the scores in the pre-test. The following statistics will explain in detail the differences in the test scores.

Table 1 presents the tests results of Group 1. The mean of pre-test is 13.37 (out of 40) and post-test 28.76. Mean difference is $15.39(p=0.000)$ and effect size - Cohen's $\mathrm{d}=3.80$ (strong). 
Table 1 Optics test results of group 1

\begin{tabular}{llll}
\hline & $\mathrm{N}$ & Mean & SD \\
\hline Post-test & 46 & 28.76 & 4.26 \\
Pre-test & 46 & 13.37 & 3.84 \\
\hline
\end{tabular}

$\mathrm{p}(2$-tailed $)=0.000$

Mean Difference $=15.39$

Cohen's d $=3.80$

Effect size Cohen's d strength:

0.00-0.20: small effect

0.21-0.50: modest effect

0.51-1.00: moderate effect

$>1.00$ : strong effect

The Cohen's d is computed as:

$$
\text { Cohen's d }=\frac{\text { Mean difference }}{\text { Pooled standard deviation }}
$$

While:

$$
\begin{aligned}
& \text { Pooled standard deviation }=\frac{(\text { SDgroup } 1+\text { SDgroup } 2)}{2}=\frac{(4.26+3.84)}{2} \\
& \text { Pooled standard deviation }=4.05
\end{aligned}
$$

Therefore: Cohen'sd $=\frac{\text { Mean difference }}{\text { Pooled standard deviation }}=\frac{15.39}{4.05}=3.80$

The Cohen's d above 1.0 indicates the effect size strong; the Cohen's d '3.80' can be considered as a very strong effect. The statistic ( $p=0.000$ and Cohen's $\mathrm{d}=3.80$ ) proves that there was a large effect with a substantial difference in the test scores achieved by the students at the beginning and at the end of the semester. The mean difference = 15.39 ( $p=0.000$, Cohen's $\mathrm{d}=3.80$ ) suggests that in Group 1 , the students' optics test scores improve considerably and significantly.

Table 1 and numbers can be explained in a simple way as the average number of correct answers which a student in Group 1 performed in the optics pre-test is 13.37 out of 40 answers; this number for the optics post-test is 28.76. It means that MorningGroup students' post-test scores were an average of 15.39 higher than their pre-test scores,. In statistical terms, if the probability value (p) is equal or less than 0.05 , the result will be considered as statically significant. The probability value '0.000' in Table 1 is substantially smaller than the specified probability value of 0.05 . Therefore, it is concluded that there was a significant increase of 15.39 (out of 40) in the optics test scores from the pre-test (prior to the model implementation) to post-test (after the model implementation).

Table 2 presents a comparison between Group 2 students' result on optics pre-test and post-test. There was a statistical significant difference between pre-test and posttest of the students in Group 2. Mean of pre-test is 12.97, and mean of post-test is 16.77. Mean difference is $3.80(p=0.004)$ and effect size - Cohen's $\mathrm{d}=0.85$.

The average number of correct answers that students in Group 2 scored in the optics pre-test is 12.97 (per 40 answers totally), and for the post-test, 16.77, so the. Mean 
Table 2 Optics test results of group 2

\begin{tabular}{llll}
\hline & $\mathrm{N}$ & Mean & SD \\
\hline Post-test & 32 & 16.77 & 6.45 \\
Pre-test & 32 & 12.97 & 2.44 \\
\hline
\end{tabular}

$\mathrm{p}(2$-tailed $)=0.004$

Mean Difference $=3.80$

Cohen's $d=0.85$

difference is 3.80 The Probability value 0.004 and Cohen's $d$ of 0.85 reveal that the optics test scores of Group 2 increased moderately and significantly.

In the post-test, group 1 mean score is statistically significantly higher than group 2 mean score

An independent sample t-test was conducted to evaluate the difference between the two groups. The students' pre-test results show that there is no statistical significant difference between Group 1 and Group 2 (mean difference $=0.445, p=0.515$ ) (Table 3), so they are considered to be similar to each other in the optics test scores at the beginning of the semester.

Table 4 describes a comparison of optics post-test results between Group 1 and Group 2. The mean of Group 1 post-test is 28.74, and 16.77 for Group 2. Mean difference is 11.96 (sig. 0.000) and effect size - Cohen's d = 2.23 (strong effect). At the end of the semester, the students in Group 1 performed about 12 answers better than the students in Group 2. The post-test results of the students in Group 1 are significantly higher than the results of Group 2.

While the CSI Model was implemented into the Optics Course for a semester, the degree of ICT application in the two groups was different. The degree of ICT application to support learning in Group 1 was higher than in Group 2. Group 1 used the online learning management system LMS to support their learning. This LMS allowed these students to upload and share their learning material including PowerPoint slides and to communicate and discuss online. Group 2 did not use the LMS at all. The students of Group 1 and Group 2 took the same optics test at the beginning and at the end of the semester. The test results of the two groups show that:

- The students' post-test scores are statistically significantly higher than their pre-test scores. This result applies for both the Morning and Afternoon group.

- At the beginning of the semester, there is no significant difference between the test scores of the two groups.

- At the end of the semester, the test scores of Group 1 were significantly higher than the test scores of Group 2.

Table 3 Optics pre-test results of group 1 and group 2

\begin{tabular}{llll}
\hline Group & N & Mean & SD \\
\hline Group 1 & 46 & 13.37 & 3.84 \\
Group 2 & 40 & 12.93 & 2.39 \\
\hline
\end{tabular}

$\mathrm{p}(2$-tailed $)=0.515$

Mean Difference $=0.45$ 
Table 4 Optics post-test results of group 1 and group 2

\begin{tabular}{llll}
\hline Group & N & Mean & SD \\
\hline Group 1 & 53 & 28.74 & 4.28 \\
Group 2 & 35 & 16.77 & 6.45 \\
\hline
\end{tabular}

$\mathrm{p}(2$-tailed $)=0.000$

Mean Difference $=11.96$

Cohen's $d=2.23$

In general, the students of Group 1, who experienced a higher degree of ICT applications,score significantly higher than the students of Group 2, who used less ICT $(p=0.000$ and effect size - Cohen's $\mathrm{d}=2.23)$.

\section{Teachers' opinions on the application of the CSI model}

Three main themes emerged from the lecturer's and the teaching assistant's interviews: (1) students engagement in learning, (2) influence of the CSI Model, and (3) a new way of teaching and learning. The following section will discuss these three main themes and then a summary will be presented.

\section{Students engaged in learning, became more active and independent}

The lecturer and the teaching assistant believed that the implementation of the CSI Model enhanced the students' learning; they believed the students became more actively engaged in optics learning, and more skilful at presenting and explaining optics during the semester. They searched for information, studied and prepared for the optics lessons and presentations. The lecturer commented:

"The students were engaged in the learning activities in the classes well."

"This week is the fourth week. From my observation, there have been positive changes. The students gained knowledge when they prepared for the lessons or carried out the tasks the lecturer required... It was quite successful."

The learning activities did not only occur inside the classroom but also outside the classroom. The resources the students used were not only the textbook as was the case the previous year, but also online resources. They were motivated and wanted to learn more about the subject. Besides becoming more dynamic and active in searching for information and preparing for the optics presentations, the students also became more active in classes. The teaching assistant noted that:

"The students made progress. They asked questions on the topics that they did not understand. I have a feeling that they want to understand more about this subject [Optics]."

The students' skills on presenting and explaining optics topics were also enhanced. At the beginning of the course, the students just read from their PowerPoint slides. But later, during the course, they introduced and explained the lessons and assignments, using PowerPoint slides to support their talk.

At the beginning, the students were quite shy, afraid of talking and asking questions. Gradually, they started to ask questions, became more confident in talking, asking 
questions of their peers and even asked the lecturer to explain sections they did not understand.

"There have been changes in the way the students present. Instead of reading, as I observed previously, they just read. Now, they have had introduction and explained to other students. They explained clearly their assignments. Regarding their presentations of the lessons, they explained the sections they understood. And there were points they did not understand, they said that they did not understand and asked the lecturer to explain for them." - The teaching assistant

"I am happy. I feel that the presenting students wanted their friends to ask them questions. It is not the same like before, they had been afraid of being questioned and afraid of not knowing how to answer the questions. Now after each section, they stopped and asked: 'Do you have any comment or questions? This is because we guide them." - The teaching assistant

\section{Influence of the CSI model}

The lecturer believed that at the time the first interview occurred - week four of the semester, the students, who experienced the implementation of the CSI model, were more engaged in learning than last-yearstudents had been. In his opinion, at the beginning of the semester, the levels of the students' engagement in learning in both years were similar. $\mathrm{He}$ also believed that the students experiencing the CSI-model-implementation became more active and independent learners.

The lecturer considered that the key factor that made a difference between the current and the previous semesters' teaching was the use of ICT and the CSI Model focussing on supporting students' learning and interaction. Implementing the CSI into his teaching practice, the lecturer was more conscious of the pedagogic aspect while using ICT in teaching than he had been last semester. He especially focussed on using ICT as a tool to enhance the interaction between teacher-students, students- students, students-learning material and to foster students' learning.

"On the request of your research, I focus more on interaction. That is the first point. The second point is that at some extent, I did not focus on learning activities of students [the previous year]. The students themselves were ... we may say ... passive [not active in learning]. If we try to stimulate them, they will work actively according to our goal." (Mr Van)

“Thanks to your intervention, the students' learning activities are increased both inside and outside classroom, students' preparation at home and online. Students are stimulated and inspired in learning." (Mr Van)

\section{A new way of teaching and learning}

Teaching The interview data also revealed that the implementation of the model provided opportunities for a new way of teaching and learning. In the aspect of teaching, because of the requirement of the research (implementing the CSI model into teaching practice), the lecturer focused more on creating learning tasks for 
students and tried to increase the level of interaction within the learning environment. Mr Van revealed:

"There are different factors which influence students' learning activities such as lecturers, the number of students in class and the nature of students (e.g. active or passive). The most vital factor is lecturers who engage students in learning activities of groups by different ways. This year, I change the strategy to organise the course by focussing more on students learning."

With this new way of teaching, the lecturer noted the changes in his students:

"If the lecturer tries to activate them, they will be much better. Therefore, for the last few weeks, I have not lectured the knowledge of the topics, but asked the students to design the presentations of the topics. Now the students' engagements in learning have improved gradually. A majority of students read the learning materials before going to class... The students of the last year groups did not read the materials as much as these groups."

In Mr Van's opinion, his teaching practice in the last-year-optics course was different:

"Last year, I did not focus on the learning activities of the students."

Van indicated that, this year, based on the model, he focused more on the students' use of ICT to support their learning. He tried to encourage the interaction between students-learning material, students-students and students-lecturer by giving the students learning tasks, checking them and motivating them. The lecturer designed learning tasks with the requirements that the students needed to search and study different learning resources, and design a group presentation on an optics topic. This way, $\mathrm{Mr}$ Van believed that he had created opportunities for the students to interact with learning resources, work in groups and discuss. The lecturer requested that the students explain optics to their peers and encouraged discussions in classes. His teaching appeared to move from more teacher-centred to more student-centred teaching practice in which teachers guided and facilitated students' learning. The lecturer smiled when he said:

"I am not teaching this year. The students present the topics."

Learning In the aspect of learning, the lecturer revealed that this way of learning was also new for students. "They never did something like this before. Now the lecturer requests them." said Mr Van.

He explained that it was because of the requirement of the lecturer; the students used the MS PowerPoint in their presentation. According to the lecturer, for most of the students, this was the first time they presented content of a course and used MS PowerPoint. Although the students were not skilful in using MS PowerPoint for presenting, they exploited the software in the aspect of presenting information. For example, besides the content, diagrams and photos related to optics, the students showed the 
photos of scientists and their biographies. They looked for online learning resources by themselves besides traditional resources.

Mr Van mentioned that he told the students that they had to be responsible for their own learning; and if they did not understand, they needed to ask. This statement was reflected in the classes. Mr Van requested the students to ask the presenting group questions in order to get more information and understand the presented topics. The questions were also to help the presenting group clarify and elaborate on their explanation. If the audience students did not ask the presenters, the lecturer questioned both audiences and presenters. He believed that this would make the students concentrate on and brainstorm the optics topics.

\section{Students' attitudes and opinions on the application of the CSI model}

Un-structured interviews with groups of students were conducted mainly at the end of the semester. Of about 90 students who participated in this research, 36 students were interviewed. The data from these interviews disclosed that students' reflection on their experience of the implementation of the CSI model focused on five main themes: (1) student perception of teaching in the Optics Course, (2) enhance physics learning, (3) ICT supported learning and (3) student concerns.

\section{Student perception of teaching in the optics course}

According to the students participating in the research, they appreciated the way of teaching optics, and thought this was a suitable teaching model. The students said that they were given opportunities to research optics topics; and this made the Optics Course different from other courses. The interviewed students indicated that this learning environment was comfortable, relaxing, enjoyable, surprising and fun; studying in this optics classes was more exciting than other classes.

"For me, this way of teaching is very good... I think that the way that the lecturer asks us to present optics topics is excellent because we can research the topics at home before going to the class."(Group 1)

"It [The learning environment] is relaxing, joyful and easily comprehensible" (Group 2)

\section{Enhance physics learning}

The students felt that this new way of teaching helped to enhance their physics learning. According to the interviewed students, this way of teaching engaged them more in learning, helped them comprehend the physics lessons faster, had a better understanding and became more active, dynamic and independent learners.

"For the Optics Course of this semester, from my observation, there is a great difference between this Optics Course and other courses. The lecturer lets us do research on each topic at home. Then we discuss in class. Students play roles of lecturers." (Group 1)

"During the process of making the presentations, besides lecture notes, I need to use other books and learning resources. For example, there are difficult terms or 
definitions; I have to study different learning resources to find explanations and definitions which are easy to understand for other students." (Group 1)

"In my opinion, when I study this optics course, my knowledge is more explicit than my knowledge from other courses. First, I work on my presentation one time, then listen to a presentation of a classmate one time and listen to the explanation of the teacher once more. Therefore, the optics knowledge is more in-depth compared with other courses. In addition, the teacher lets us comfortably exchange our ideas and look for online resources. I think this helps us enrich our knowledge.” (Group 2)

"When the lecturer gives us tasks, we will understand specific work to do at home. We become more active in studying knowledge. When we want to stand in front of our classmates to talk, we need to understand the knowledge deeply and in details so that we can talk." (Group 1)

The interviewed students believed that this way of teaching helped them develop necessary skills for learning including skills of working with computers, seeking information, presenting and explaining ideas.

"I believe that when I study this course, I have developed skills such as the skill of talking in public, skill of working with computers and find information online."

(Group 2)

\section{ICT supported learning}

Student interview data revealed that ICT played an important role in supporting their learning. Two themes that related to students' applications of ICT into learning emerged from the data: (1) ICT promoting social interaction and (2) ICT supporting individual learning.

The students used ICT to support face-to-face presentations. From these students' point of view, using ICT (e.g., images, photos and videos clips) helped to attract their classmates' attention and helped make learning become enjoyable:

"When teaching with ICT, we have photos and video clips. This attracts students' attention." (Group 2)

"PowerPoint presentations help students study more easily, help reviewing lessons become relaxing and enjoyably, make learning more surprising and exciting." (Group 2)

In addition to face-to-face discussion, the students found that online discussion was also useful as this enabled them to discuss in detail, and to see and hear the phenomena. The students could also instantly look for online learning resources to support the discussion.

"When we need to discuss in details, we cannot discuss by phone calls or messages. Discussing via phone limits us for observing details of phenomena.... We can see, 
hear and discuss synchronously via the internet. While we are discussing if my friends feel that they do not satisfy with one section or this section is not quite accurate, my friends can instantly look for different learning resources on the internet." (Group 1)

Data from the students' interviews also disclosed that they predominantly used ICT as a tool to help them look for learning resources:

"The Optics Course in this semester requires us to find information. Naturally, we need computers. For example, for assignments and models, we need to search them online." (Group 2)

The students noted that as a requirement of the Optics Course, they needed to search for information online. Google was considered by the students as a useful tool for searching for information. The students said that optics information on this search engine was rich and diverse, and to deal with the information, the students disclosed that they needed to analyse and compare it.

"If I want to research about something, I just go online and 'google'." (Group 1)

"Another advantage is that information on Google is very diverse and rich. For example, when we look for specific information on Google, related information also appear below the needed link [that connects to the specific information]. We can find the related information; the text books don't have such advantages. There are different sources so that we can compare and reflect." (Group 1)

The articles listed on the Learning Management System were also appreciated by the students because they were from different authors and different sources. In addition, the articles also contained information which was not available from the textbook.

"One of the strong points of the e-learning system is that teachers post articles from different authors relating to each topic. Some knowledge in the articles is not available in the textbook. So we can research more from the articles of different authors and different places [website] to search for information." (Group 1)

ICT was utilised by the students as a useful tool to acquire information. Besides this, the students commented that the use of ICT supported internalising and remembering knowledge:

"Using ICT to teach helps students to internalise [knowledge] more easily because when teaching without ICT, it is dry and boring." (Group 2)

"There are some issues we cannot remember, but when seeing the pictures on the screen, we can remember." (Group 2)

\section{Student concerns}

Data analysis from the students' interviews showed that there were three main weaknesses of the Optics Course in the students' view: time consuming, students' unclear 
explanation, and technology barriers. Some students complained that it took them a lot of time to study optics. One student said that he took many courses at the same time so he did not have enough time to study other courses while investing much time on optics.

"For me, this way of teaching is very good. But for me, now I study too many courses at the same time, and time is important for me. And the time which I spend on studying optics occupies majority of my time. I don't have enough time to study other courses." (Group 1)

While some students considered investing much time in studying optics outside the class was a weakness, a majority of them thought it was a strong point:

"For me, this way of teaching is very good." (Group 1)

"Preparing for lessons before going to class depends on ... one is hard-working or not. Some people like [this way], some people do not like. It requires hard-workingcharacteristic of people. Reading material before going to class is very good." (Group 2)

\section{Discussion and conclusion}

In the context of this research, the implementation of the CSI Model helped enhancing students' physics content knowledge. The optics test results showed that post-test results were significantly higher than the pre-test results. Moreover, it is indicated from the findings that the students who experienced a higher degree of ICT applications in the light of the CSI Model implementation tended to perform better in the optics test than the students who used less ICT. The students in Group 1 used more applications of ICT to support their learning through an online management system. The students in Group 2 used less applications of ICT to support learning. The use of ICT in both groups was of course underpinned by the CSI Model. At the end of the semester, the score of the students, who used ICT at the highest degree, (Group 1) was statistically significantly higher than the score of the students who used ICT at lower degree (Group 2). It was noted that there was no significant different between the pre-test results of the two groups.

The students' enhanced learning was indicated by their learning activities during the semester. The students were engaged deeply in learning. They researched the optics topics in advance by searching information from different websites, books and the textbook. They engaged in group work and assignments, shared the workload, discussed and prepared group presentations on optics topics. They shared their knowledge in class with MS PowerPoint presentations, explained the optics topics, asked and answered questions, discussed and commented. The students believed that this way of teaching helped them to comprehend the optics lessons more easily and faster, as well as obtain deeper and richer understandings of optics. In addition, studying optics for these students was fun, exciting and joyful. The students became more active and independent in their learning. Their skills such as ICT skills, skills of seeking information, presenting and explaining ideas were developed. They also became more confident, motivated, dynamic and active in their learning. In addition, their skills in presenting 
and explaining optics topics were improving during the course. The above results suggest that ICT is a useful tool to enhance students' physics learning and students' physics performance, which confirm the findings of the earlier work by (Christina and Dimitrios 2008), (Wang 2009) and (Driver and Scott 1996).

As mentioned earlier, Vietnam's educational reform is to change education from a teacher-centred to a student-centred, using ICT in education as one way to achieve this goal. Research shows that the teaching and learning approach in Vietnam is still rather teacher-centred (Pham 2010; Stephen, et al. 2006). Vietnamese teachers are now facing the challenges of technology-driven education. Their essential need is to acquire new understandings and skills in using ICT to support teaching in the light of a studentcentred approach (Harman and Nguyen 2010), but very little national literature covers on this area and meets their needs.

The successful implementation of the CSI Model in this study suggests some possible implications at different levels of educational system. At the teacher level, the CSI Model can provide a rationale for teachers' use of ICT to support teaching.

For teacher training and professional development purposes, the current study can provide teachers with insight and understandings on how to use ICT to assist students' individual and social learning. On the social aspect of learning, ICTs may be used as tools to promote interactions between students-teacher, students- students and students-learning resources.

Learning styles of Vietnamese students are strongly influenced by Confucian beliefs. It is argued that under this influence, a learning style which contains cooperation and interaction is not natural for Vietnamese students (Pham 2008). This study shows that it is possible to develop cooperative and interactive learning in the Vietnamese context.

At the level of Vietnam's Ministry of Education and Training (MOET), this study can provide possible guidance for the current strategy of implementing ICT into education. Although Vietnam's MOET educational reforms promote the use of ICT to support teaching with a student-centred approach, a teacher-centred approach still dominates Vietnamese classrooms. The current study shows how ICT was used to enhance student-centred learning. Training Vietnamese teachers on implementing the CSI Model into their teaching practice is a possible means to help the MOET achieve the goal of the educational reform.

At the research level, there is little searchable research on the integration of ICT in teaching physics in Vietnam. The current study contributes to this literature with insights into the use of ICT in teaching Physics in the Vietnam context.

The CSI Model is a pedagogic model integrating constructivist and sociocultural learning principles with ICT. Within the context of this study, this research reveals that this model can effectively enhance students' physics learning. Mr Van - the participant lecturer - concluded that the CSI Model "is a suitable pedagogic model for University $\mathrm{X}$ [his university] in particular and for Vietnam in general... It is very useful for teaching practice where ICT is implemented".

Authors' contributions

Both authors contribute to the idea and writing of the manuscript. Both authors read and approved the final manuscript. 


\section{Author details}

${ }^{1}$ Can Tho University, Can Tho, Vietnam. ${ }^{2}$ Curtin University, Perth, Australia. ${ }^{3}$ TEMS Education Research Centre, the University of Waikato, Private Bag 3105, Hamilton 3240, New Zealand.

Received: 29 December 2015 Accepted: 8 June 2016

Published online: 14 June 2016

\section{References}

Amanatidis, N (2014). An in service training course,(INSET) on ICT pedagogy in classroom instruction for the Greek primary school teachers. Education and Information Technologies, 19(2), 307-326.

Brown, JS, Collins, A, \& Duguid, P (1989). Situated cognition and the culture of learning. Educational Researcher, 18(1), 32-42.

Butter, MC, Pérez, LJ, \& Quintana, MGB (2014). School networks to promote ICT competences among teachers. Case study in intercultural schools. Computers in Human Behavior, 30, 442-451.

Campbell, DT, \& Stanley, J (1963). Experimental and quasi-experimental designs for research on teaching. Boston: Houghton Mifflin.

Christina, S, \& Dimitrios, K (2008). The role of constructivist educational software on students' learning regarding mechanical interaction. Education and Information Technologies, 13(3), 185-219. doi:10.1007/s10639-008-9058-8.

Cobb, P, \& Bowers, J (1999). Cognitive and situated learning perspectives in theory and practice. Educational Researcher, 28(2), 4-15.

Cohen, L, Manion, L, \& Morrison, KRB (2011). Research methods in education (7th ed.). New York: Routledge.

Cole, M (1995). Socio-cultural-historical psychology: some general remarks and a proposal for a new kind of cultural genetic methodology. In J. V. Wertsch, P. del Río, \& A. Alvarez (Eds.), Sociocultural studies of mind (pp. 187-214). New York: Cambridge University Press.

Cole, M, \& Wertsch, JV (1996). Beyond the individual-social antinomy in discussions of Piaget and Vygotsky. Human Development, 39(5), 250-256.

Collis, B, \& Moonen, J (2001). Flexible learning in a digital world. Experiences and expectations. London: Kogan Page.

Driver, R (1988). Theory into practice II: a constructivist approach to curriculum development. In P. Fensham (Ed.) Development and dilemmas in science education (pp. 133-149). London: The RoutledgeFarmer.

Driver, R, \& Oldham, V (1986). A constructivist approach to curriculum development in science. Studies in Science Education, 13(1), 105-122. doi:10.1080/03057268608559933.

Driver, R, \& Scott, PH (1996). Curriculum development as research: a constructivist approach to science curriculum development and teaching. In D. F. Treagust, R. Duit, \& B. J. Fraser (Eds.), Improving teaching and learning in science and mathematics (pp. 94-108). New York: Teachers College Press.

Fosnot, CT, \& Perry, RS (2005). Constructivism: a theory of learning. In C. T. Fosnot (Ed.), Constructivism: theory, perspectives, and practice (pp. 8-38). New York: Teachers College Press.

García-Valcárcel, A, Basilotta, V, \& López, C (2014). ICT in collaborative learning in the classrooms of primary and eecondary education. Comunicar, 21(42), 65.

Greeno, JG (1997). Response: on claims that answer the wrong questions. Educational Researcher, 26(1), 5-17. doi:10.2307/1176867.

Harman, K, \& Nguyen, TNB (2010). Reforming teaching and learning in Vietnam's higher education system. In G. Harman, M. Hayden, \& T. N. Pham (Eds.), Reforming higher education in Vietnam (pp. 65-86). London: Springer.

Jonassen, D, Davidson, M, Collins, M, Campbell, J, \& Haag, BB (1995). Constructivism and computer-mediated communication in distance education. American Journal of Distance Education, 9(2), 7-26.

Jonassen, D, Carr, C, \& Yueh, H-P (1998). Computers as mindtools for engaging learners in critical thinking. TechTrends, 43(2), 24-32.

Kamali-Mohammadzadeh, F, Behzadi, M-H, Shahvarani, A, \& Hosseinzadeh-Lotfi, F (2014). Study on the effect of crocodile ICT 605 software on mathematics learning for teaching flowchart based on constructivism theory. In Mathematics education trends and research.

Lave, J, \& Wenger, E (1991). Situated learning: legitimate peripheral participation. Cambridge: Cambridge University Press

Meleisea, E (2007). The UNESCO ICT in education programme. Bangkok: United Nations Educational, Scientific and Cultural Organization.

Muijs, D (2004). Doing quantitative research in education. London: Sage Publications.

National Assembly of Vietnam (2000). Nghị quyét của quốc hội nước Cộng Hòa Xã hội chủ nghĩa Vệt Nam số 40/2000/QH10 ngày 09 tháng 12 năm 2000 về đổi mói chưong trình giáo duc phổ thông [The resolution of The Socialist Republic of Vietnam National Assembly no. 40/2000/QH10 December 09 ${ }^{\text {th }}, 2000$ on secondary educational programme reform]. Vietnam.

Ojugo, A, Osika, A, lyawa, I, \& Yerokun, R (2013). Information and communication technology (Ict) integration into science, technology, engineering and mathematic (Stem) in nigeria. West African Journal of Industrial and Academic Research, 4(1), 148-156.

Ozkal, K, Tekkaya, C, Cakiroglu, J, \& Sungur, S (2009). A conceptual model of relationships among constructivist learning environment perceptions, epistemological beliefs, and learning approaches. Learning and Individual Differences, 19(1), 71-79.

Pea, RD (1997). Practices of distributed intelligence and designs for education. In G. Salomon (Ed.), Distributed cognitions: psychological and educational considerations. New York: Cambridge University Press.

Peeraer, J, \& Van Petegem, P (2011). ICT in teacher education in an emerging developing country: Vietnam's baseline situation at the start of 'The Year of ICT'. Computers \& Education, 56(4), 974-982. doi:10.1016/j.compedu.2010.11.015.

Pham, THT (2008). The roles of teachers in implementing educational innovation: the case of implementing cooperative learning in Vietnam. Asian Social Science, 4(1), 3-9.

Pham, THT (2010). Implementing a studentcentered learning approach at Vietnamese higher education institutions: Barriers under layers of casual layered analysis (CLA). Journal of Futures Studies, 15(1), 21-38. 
Prime Minister of Vietnam (2005). Nghị quyết 14/2005/NQ-CP về đổi mói cơ bản và toàn diện giáo duc đại học Việt Nam giai đoạn 2006-2020 [The resolution no. 14/2005/NQ-CP on fundermental and comprehensive higher education reform in Vietnam for the period of 2006 - 2020].

Rovai, AP (2004). A constructivist approach to online college learning. The Internet and Higher Education, 7(2), 79-93.

Salomon, G (1998). Novel constructivist learning environments and novel technologies: some issues to be concerned with 1 This paper is based on the author's Keynote Address presented at the 7th EARLI Conference, Athens, Greece, August 1997. 1. Learning and Instruction, 8, 3-12. doi:10.1016/S0959-4752(98)00007-3.

Salomon, G, \& Perkins, D (1996). Learning in wonderland: What computers really offer education. In S. Kerr (Ed.), Technology and the future of education. NSSE yearbook (pp. 111-129). Chicago: University of Chicago Press.

Salomon, G, \& Perkins, DN (1998). Chapter 1: individual and social aspects of learning. Review of Research in Education, 23(1), 1-24. doi:10.3102/0091732X023001001.

Stephen, W, Doughty, P, Gray, PJ, Hopcroft, JE, \& Silvera, IF (2006). Observatoins on undergraduate education in computer science, electrical engineering, and physics at select universities in Vietnam. Retrieved from http://home.vef.gov/ download/Report_on_Undergrad_Educ_E.pdf.

UNESCO (2005). Regional guidelines on teacher evelopment for pedagogy-technology integration. Bangkok: UNESCO Asia and Pacific Regional Bureau for Education.

Vietnam's Ministry of Education and Training (2008). Chỉ thị số 55/2008/CT- BGDĐT về tăng cường giảng dạy, đào tạo và úng dụng công nghệ thông tin trong ngành giáo duc giai đoạn 2008-2012 [Directive no. 55/2008/CT- BGDĐT on promoting teaching, training and applying ICT in education - Period 2008-2012]. Ha Noi: Author.

Von Glasersfeld, E. (1989). Cognition, construction of knowledge, and teaching. Synthese, 80(1), 121-140.

Walliman, N (2006). Social research methods. London: Sage Publications.

Wang, Q (2009). Designing a web-based constructivist learning environment. Interactive Learning Environments, 17(1), 1-13. doi:10.1080/10494820701424577.

Watts, M, \& Pope, M (1989). Thinking about thinking, learning about learning: constructivism in physics education. Physics Education, 24(6), 326-331.

\section{Submit your manuscript to a SpringerOpen ${ }^{\circ}$ journal and benefit from:}

- Convenient online submission

- Rigorous peer review

- Immediate publication on acceptance

- Open access: articles freely available online

- High visibility within the field

- Retaining the copyright to your article

Submit your next manuscript at $\boldsymbol{\nabla}$ springeropen.com 